Holger Rohn, Nico Pastewski, Michael Lettenmeier, Klaus Wiesen, Katrin Bienge

\title{
Resource efficiency potential of selected technologies, products and strategies
}

Originally published as:

Rohn, H. ; Pastewski, N. ; Lettenmeier, M. ; Wiesen, K. ; Bienge, K. (2014):

Resource efficiency potential of selected technologies, products and strategies In: Science of The Total Environment, 473-474, 32-35. 
Holger Rohn ${ }^{a *}$, Nico Pastewski ${ }^{b}$, Michael Lettenmeier ${ }^{c}$, Klaus Wiesen ${ }^{c}$, Katrin Bienge ${ }^{c}$

\section{Resource efficiency potential of selected technologies, products and strategies}

a Trifolium-Beratungsgesellschaft mbH, Alte Bahnhofstraße 13, 61169 Friedberg, Germany

${ }^{b}$ Fraunhofer Institute for Industrial Engineering IAO, Nobelstr. 12, 70569 Stuttgart, Germany

C Wuppertal Institute for Climate, Environment and Energy, Döppersberg 19, 42103 Wuppertal, Germany

* Corresponding author: Holger Rohn, Trifolium-Beratungsgesellschaft mbH, Alte Bahnhofstraße 13, 61169 Friedberg, Germany

E-mail: holger.rohn@trifolium.org

Phone: +4960316875464

Fax: +4960316875468 


\title{
Resource efficiency potential of selected technologies, products and strategies
}

\author{
Holger Rohn ${ }^{1}$, Nico Pastewski ${ }^{2}$, Michael Lettenmeier ${ }^{3}$, Klaus Wiesen $^{3}$ and Katrin Bienge ${ }^{3}$ \\ ${ }^{1}$ Trifolium - Beratungsgesellschaft mbH, Alte Bahnhofstraße 13, 61169 Friedberg, Germany \\ ${ }^{2}$ Fraunhofer Institute for Industrial Engineering IAO, Nobelstr. 12, 70569 Stuttgart, Germany \\ ${ }^{3}$ Wuppertal Institute for Climate, Environment and Energy, Döppersberg 19, 42103 Wuppertal, Germany
}

\begin{abstract}
Despite of rising prices for natural resources during the past 30 years, global consumption of natural resources is still growing. This leads to ecological, economical and social problems. So far, however, limited effort has been made to decrease the natural resource use of goods and services. While resource efficiency is already on the political agenda (EU and national resource strategies), there are still substantial knowledge gaps on the effectiveness of resource efficiency improvement strategies in different fields. In this context and within the project "Material Efficiency and Resource Conservation", the natural resource use of 22 technologies, products and strategies was calculated and their resource efficiency potential analysed.
\end{abstract}

In a preliminary literature- and expert-based identification process, over 250 technologies, strategies, and products, which are regarded as resource efficient, were identified. Out of these, 22 subjects with high resource efficiency potential were selected. They cover a wide range of relevant technologies, products and strategies, such as energy supply and storage, Green IT, transportation, foodstuffs, agricultural engineering, design strategies, lightweight construction, as well as the concept "Using Instead of Owning". To assess the life-cycle-wide resource use of the selected subjects, the material footprint has been applied as a reliable indicator. In addition, sustainability criteria on a qualitative basis were considered.

The results presented in this paper show significant resource efficiency potential for many technologies, products and strategies.

Keywords: resource consumption, resource efficiency, material footprint, MIPS, potential analysis.

\section{Introduction}

The world economy is expected to grow by three percent each year until 2030. By 2050, more than 9 billion humans will live on earth and an increased number will live in cities and/or industrial societies (see BMU 2007). This growth in economic activity and population increases resource demand. Added pressure on the environment, due to increasing resource use, related emissions, and waste disposal, leads to ecological but also economical and social problems. Insecurities in supply, shortages of resources, raw material conflicts, and high and strongly fluctuating raw material prices can result in massive economical and social crises around the world. The inefficient use of resources can cause disadvantages for competition and thereby endanger the development of jobs and companies.

This paper presents the overall results of task 1 ("Identification of innovative lead products, lead technologies, and lead markets increasing resource efficiency") (see Rohn et al. 2010a) 
of the project "Material Efficiency and Resource Conservation“1 (project duration 2007 2010). The following sections summarise 22 potential analyses of different technologies, products and strategies, which were identified using a cross-sectional selection process. The selection process was based on desk research and a survey involving experts from university and non-university research institutes and organisations as well as associations, initiatives, and companies. It resulted in a Top20 list of relevant topic areas for resource efficiency. Within these areas a commonly used technology, product or strategy and an alternative with presumed resource efficiency were selected. The potential analysis was performed by comparing the resource use of the commonly used option with its alternative. To calculate the overall resource saving potential, the resource consumption was extrapolated to a national level either by assuming that the presumably more resource efficient alternative substitutes the commonly used option completely or by using existing scenarios. In the end, potentials were identified on a micro and on a macro level. On the micro level, potentials in the entire life cycle of each subject were identified. On a macro level, the question of how much the analysed subject could aim in reducing resource consumption on a national level was explored.

To measure the life-cycle-wide resource use, the method Material Input Per Service unit (MIPS) was applied (Schmidt-Bleek et al. 1998, Liedtke et al. 2013). MIPS is an approach, which allows to measure all natural resources taken from nature (material input) to provide a specific service or benefit to be defined by the service unit. In contrast to models in ISO $14040 / 44$ life cycle assessment there is no impact assessment. As all emissions and related impacts result from the extraction of natural resources, a reduction of the inputs can also lead to a decrease of all emissions and environmental impacts.

The material inputs are divided in up to five resource categories, which are measured in kilograms or tons:

- $\quad$ Abiotic resources (e.g., minerals, and fossil fuels)

- $\quad$ Biotic resources (e.g., from agriculture)

- Water (surface, ground and deep ground water)

- $\quad$ Air (e.g., chemically changed particles)

- $\quad$ Soil movements in agriculture and silviculture

Although a product may be very resource efficient in one category, it can be determined as not resource efficient, if it shows comparably high material inputs in other categories. The resource categories are therefore looked at and compared separately. To consider all data life cycle wide, material intensity factors (MIT-factors) are being used. MIT-factors for different types of materials, modules, and services are available online, published by the Wuppertal Institute (Wuppertal Institute 2013). The methodology of the resource efficiency potential analysis is further described in Rohn et al. (2010b).

\section{Cross-sectional and enabling technologies: "Door openers" for resource efficient applications}

Due to the manifold possibilities of their application, cross-sectional technologies can carry high resource efficiency potential. In this field, four potential analyses were conducted:

- Assessment of resource efficiency in sewage water filtration

- Comparison of direct and indirect storage for electric vehicles

- Resource efficiency potential in heat storage

\footnotetext{
${ }^{1}$ Project website http://ressourcen.wupperinst.org
} 
- Resource efficiency potential in insulation material production

The resource efficiency potential of using membrane technologies in municipal sewage plants of a certain size was analysed. With respect to the approximately 1,000 existing plants of this type in Germany, the potential was estimated to be remarkable, especially for new but also for refit plants. Furthermore, there are 9,000 plants of a different type for which additional resource efficiency potential is expected. Additionally, there are a number of other fields of application, e.g. drinking water purification (e.g. desalinisation and softening), food production, or grey water processing, for which product-integrated environmental protection is relevant (see Leck, 2010).

To guarantee a more extensive use of core developments such as renewable energies and to realise resource efficiency potential, enabling technologies, which increase resource efficiency, need to be easily available. However, the comparison of electric vehicles and fuel cell cars shows that this potential is only fully revealed by taking into consideration the complete life cycles. The production process of the energy storage system for the fuel cell car is notably more resource efficient than that of the "classic" electric vehicle. This is more than offset during the use phase (due to the extremely high energy consumption in the generation of hydrogen by means of electrolysis). In comparison to conventional drive systems (e.g. diesel car), the efficiency potential of the electric vehicle is only viable by changing the composition of the electricity mix (high percentage of renewable energy) (see Rohn et al., 2010b).

Minor differences between possible alternatives can have major effects. In the case of the analysed insulation materials made of EPS (expanded polystyrene) hard foam, e.g., a minor change of the composition of the insulation material (by adding graphite) resulted in resource savings of about one third (see Schniering, 2010).

\section{Renewable energies facilitate substantial resource savings}

In this section, the results of the following potential analyses are presented:

- Resource efficiency potential of wind energy and biomass

- Resource efficient large-scale energy production: potentials of Desertec

- Resource efficient energy production by photovoltaics

In comparison to the electricity mix in Germany in 2008, the renewable energies explored offer increases in resource efficiency for electricity generation. The specific use of resources of all analysed variants is comparably small, the use of abiotic materials and water makes up only a fraction of that necessary for coal-fired power or for the electricity mix in 2008. With regard to the consumption of biotic materials and air, biomass, in the form of renewable raw materials, is the only alternative that shows poorer results than the average electricity mix.

The specific use of resources is also determined by the build-up of an appropriate infrastructure. With regard to offshore wind farms, this concerns the grid connection to the mainland as well as the manufacture of the plants (head mass, tower and foundation). Regarding other forms of renewable energies (onshore wind farm and biomass), capacities are limited e.g. by a lack of suitable new sites or because current plants are located at high wind yield sites. Moreover, they may compete with other uses, such as agriculture, or may be in conflict with nature conservation. In that respect, the repowering of existing plants or farms is the central option. The analysis of the biogas plant examined shows that especially the type of substrates used, the fertilizer application, and the transport distances of the substrate have a relevant influence on the overall resource consumption of the power provided. The 
size of the plant matters as well as the possibilities of using the waste heat of electricity production (e.g. by local heat grids) (see Wiesen, 2010).

With the Desertec concept, a globally applicable solution for the large-scale use of solar thermal power plants is developed. Based on current results, the solar tower as a technology option offers the highest resource efficiency among the compared solar thermal plants, performing better than parabolic plants and Fresnel collectors (see Samus, 2010).

Photovoltaics offers a high potential because of its decentralised use. The results of the analysis show that thin layer technology offers a considerable resource conservation potential compared to multicrystalline silicon thick-film modules (see Cholewa, 2010).

\section{The growing information and communication technology (ICT) market needs a careful resource management}

In this section the results of three potential analyses are presented:

- Green information technology (IT): Resource efficiency potential of server based computing

- Green information technology (IT): Resource efficiency increase with ICT comparison of displays

- Resource efficient design concepts of a mobile phone

- Resource efficiency potential of recycling small electric and electronic appliances by separation from mixed household waste using radio-frequency identification (RFID) labelling of primary products

Due to the increasing amount and the short life span of IT products, the annual consumption of resources in this sector rises continuously. A comparison of two systems with equal performance, "desktop computer" and "thin clients" (server-based computing on terminals connected to a central server), reveals that the server-based variant is considerably more efficient in all resource categories. The potential analysis also shows that variants with high resource efficiency according to their respective material footprint are often also more economical with regard to strategically interesting metals such as silver, gold, palladium, tantalum, copper, nickel, chrome and iron (see Maga, 2010).

With the switch from cathode ray tube (CRT) to Liquid Crystal Displays (LCD), the resource efficiency potential of the latter has been largely exploited. The analysis revealed a high efficiency potential for the expanded dissemination of Organic Light Emitting Diode (OLED) Displays. In comparison to LCDs and Plasma Display Panels (PDP), resource efficiency of different material categories can be increased three to six fold during the use phase. However, possible rebound effects, due to increasing size and use of screens, should be considered (see Werner et al., 2010).

With respect to mobile phones, resource efficiency can be optimized through design. Resource efficiency potentials can be realised through longer life spans or reduced "resource-light" concepts of mobile phones. Smartphones can carry resource-saving potentials when they completely substitute other appliances and their purchase / manufacture. It depends on the buying and usage patterns whether this potential can be exploited (see Simon et al., 2010).

The disposal of ICT appliances is a problem with regard to resource efficiency. Currently, it is almost impossible to recycle LCDs and PDPs economically. Furthermore, out of convenience, many small electric and electronical appliances are disposed of in the household waste. Thus, they are often incinerated instead of being recycled or reused. 
Marked with passive radio-frequency identification (RFID) labels, electric and electronic appliances could be more easily identified and, therefore, recycled or reused, which could save resources (see Udes, 2010).

\section{Food - both production and consumption need to be considered}

In this field of action, resource efficiency potentials of agricultural technologies and food production were analysed. This section refers to two potential analyses:

- Resource efficiency potential of intelligent agricultural technologies with the example of the application of nitrogen sensors for fertilization

- Resource efficiency potential in food production - examples fish, fruits, vegetables

On the supply side, resource efficiency potential was identified in more sustainable farming and fishing methods as well as in more efficient irrigation methods and safer use of pesticides. This means, e.g., reducing by-catches in fishing, reducing energy consumption in greenhouses, or using waste heat from greenhouses. A further interesting approach is the use of nitrogen sensors to save pesticides and to increase yields (see Schimanski, 2010).

The food production analyses show that different, rather small measures in resource efficiency, in sum, can make a substantial contribution. However, even though resource potentials can be realised in food production, there is, most probably, considerably higher potential on the consumer side. For example, the choice of transportation for shopping can realise substantial savings. Other studies show that savings potential can be increased in waste prevention on both the production and the consumption side. Furthermore, in consumption, the diet and the form of preparation are very relevant to resource use. The analyses also confirmed the finding that seasonal considerations in the choice of vegetables and fruits have a strong influence on resource conservation (see Rohn et al., 2010).

\section{Traffic - Infrastructure bears higher resource efficiency potential than drive systems}

This section deals with the results of the potential analyses carried out in the field of transportation:

- Assessment of resource efficiency potential in freight transportation

- Resource efficiency potential of electric vehicles

Due to its high level of resource consumption and its central importance for all social and economical spheres, transportation is a focus area in any attempt to increase resource efficiency and reduce emissions.

Based on the example of a municipal commercial vehicle, the comparison of electric and diesel drive shows that the use of electric vehicles could reduce greenhouse gas (GHG) emissions and increase independence from mineral oil. Nevertheless, certain limiting conditions need to be taken into account: The level of resource efficiency is primarily dependent on the electricity mix (see Reichardt, 2010). This correlation can be transferred to rail traffic as well. A switch to lightweight constructions is also a measures which could reduce fuel consumption. Likewise, an intelligently controlled deployment of vehicles using innovative telematics systems could potentially increase resource efficiency. The use of modern traffic telematics could possibly mitigate the necessity for more extensive infrastructure and facilitate the exploitation of further potential. 
Construction and maintenance of the infrastructure for the respective carriers are the major sources of resource consumption in freight transportation, particularly in rail traffic. This has often been neglected in sustainability considerations so far. However, it bears great potential even though the build-up of transportation infrastructure in Germany has been largely completed due to demographic reasons. The future reduction of road width is one possible step to increase resource efficiency (see Aydin, 2010).

\section{Integrating resource efficiency into product development}

In this field, resource efficiency criteria in product development processes were explored and potentials of several materials were analysed within three potential analyses:

- Consideration of resource efficiency criteria in product development processes

- Resource efficiency potential of the implementation of light-weight construction using new materials

- Resource efficiency potential of high- and ultrahigh-strength steel

From a number of previous studies we know that product development processes carry the potential to significantly reduce the environmental impact throughout the entire life cycle of a product, as there are many parameters that can be influenced. Along the progression of the development process, product parameters are increasingly determined and, correspondingly, future environmental impacts are determined more and more. Therefore, attempts to increase resource efficiency throughout the life cycle ought to be addressed at an early stage of the product development process. By integrating the MIPS concept and general criteria for resource efficiency, a design method that accompanies the development process has been established. This enables the designer to assess and reduce resource consumption of products throughout the entire lifecycle (see Hufenbach et al., 2010).

The relevance of the integrative, life-cycle-oriented product development process was validated in the examination of a lightweight constructed seat shell made of a textilereinforced thermoplastic material. Combined with a lightweight construction design and highly productive processing, the life-cycle-wide resource consumption of the automobile seat shell can be significantly reduced. The lower mass of the newly developed lightweight seat shell contributes to a reduction of fuel consumption in the use phase (see Rothenberg, 2010).

Further potential analyses showed that the advancement of materials is suitable for reducing resource consumption. In comparison to conventional steel constructions, the use of highand ultrahigh-strength steels for lightweight constructions in automobiles revealed a fuel savings potential of $0.7 \mathrm{I} / 100 \mathrm{~km}$ during the analyses. Further considerable resource consumption savings can only be realised in combination with innovative casting procedures (Sadeghi and Kuhrke, 2010).

\section{Resource efficiency-oriented business models: product-service systems require rethinking}

One approach to increase resource efficiency is to understand resource orientation as an integral part of the business strategy and to implement it in corresponding business models. Two potential analysis were made:

- Resource efficiency potential of production on demand 
- Resource efficiency potential of "Using Instead of Owning" in a business-to-business (B2B) context

"Production on demand" is the most far-reaching type of "order-driven" production, which ideally, prevents overproduction. Quantitative resource efficiency potentials were determined with the example of journals. The concept "production on demand" starts from the customer side: They need to order as early as possible because the quantities produced equal the quantities ordered (avoiding overproduction). Compared to stock-based storage, this results in longer lead times for customers. This rethinking process can be identified as a chance for the realisation of resource efficiency potentials, but, at the same time, as a barrier to its concrete implementation (see Kim, 2010).

The concept "Using Instead of Owning" forces suppliers to reorganise their sales-oriented business strategy towards service-oriented ways of thinking. Core components are accompanying the customers throughout the use phase of the product and re-designing the product after the use phase. The potential analysis of a robot employed according to the principle "Using Instead of Owning" revealed that by reusing the robot, about half of the resource consumption during production could be saved. Since operating energy makes up the highest consumption share, increasing energy efficiency also bears savings potential (see Pacholack, 2010).

\section{Conclusions}

The potential analyses provided interesting and resource-relevant starting points for a broad discussion on resource efficiency. The analyses, in part, identified substantial potential for resource conservation. Some results go hand in hand with common sustainability criteria, others open up new perspectives (see Rohn et al., 2010a).

To achieve substantial dematerialisation (key word "factor 10"), different measures need to be taken into account engaging key players to realise the potentials identified and to reveal further potentials. Additional activities beyond the 22 subjects presented within the project "Material Efficiency and Resource Conservation" are necessary. The network of universities integrating the paradigm of resource efficiency into research and training ought to be considerably extended.

\section{References}

Aydin, Cengizhan / Kuhrke, Benjamin / Lettenmeier, Michael (2010): Ermittlung von Ressourceneffizienzpotenzialen der Verkehrssysteme am Beispiel des Güterverkehrs. In: Rohn, Holger I Pastewski, Nico / Lettenmeier, Michael (2010): Technologien, Produkte und Strategien - Ergebnisse der Potenzialanalysen. Ressourceneffizienzpaper 1.5., Wuppertal Institut Wuppertal

Cholewa, Anna (2010): Ressourceneffiziente Energieerzeugung: Bereich Photovoltaik, Studienarbeit, RWTH Aachen

Eberhard, Almuth / Lukas, Melanie / Stöwer, Lene / Rohn, Holger / Lettenmeier, M. / Teitscheid, Petra (2010): Potenziale zur Ressourceneffizienzsteigerung in der Lebensmittelproduktion am Beispiel Obst, Gemüse und Fisch. In: Rohn, Holger / Pastewski, Nico / Lettenmeier, Michael (2010): Technologien, Produkte und Strategien - Ergebnisse der Potenzialanalysen. Ressourceneffizienzpaper 1.5., Wuppertal

Heynen, Alain / Büttgen, Eberhard (2010): Ressourceneffiziente Energiespeicherung: Vergleich von direkter und indirekter Speicherung in elektrifizierten PKW. In: Rohn, Holger / Pastewski, Nico / Lettenmeier, Michael (2010): Technologien, Produkte und Strategien - Ergebnisse der Potenzialanalysen. Ressourceneffizienzpaper 1.5., Wuppertal Institut. Wuppertal.

Hufenbach, Werner / Kupfer, Robert / Lucas, Peter (2010): Ressourceneffizienz im Produktentwicklungsprozess. In: Rohn, Holger / Pastewski, Nico / Lettenmeier, Michael (2010): Technologien, Produkte und Strategien Ergebnisse der Potenzialanalysen. Ressourceneffizienzpaper 1.5., Wuppertal. 
Kim, Simon (2010): Ressourceneffizienzpotenziale durch Production on demand. Studienarbeit, Institut für Arbeitswissenschaften und Technologiemanagement, Universität Stuttgart

Leck, Matthias (2010): Ermittlung von Ressourceneffizienzpotenzialen im Bereich der Wasserfiltration durch Membrantechnologie, Institut für Produktionstechnik und Logistik, Fachgebiet Umweltgerechte Produkte und Prozesse, Kassel

Liedtke, Christa / Bienge, Katrin / Wiesen, Klaus / Teubler, Jens / Greiff, Kathrin / Lettenmeier, Michael / Rohn, Holger (2013): Resource use in the production and consumption system - the MIPS approach. Resources. 2013, Reviewing Progress in Material Intensity Analysis for Transition towards Sustainable Resource Management

Maga, Daniel (2010), Ressourceneffizienzpotenziale der Green IT und Umweltexternalitäten als Ursache für ein Marktversagen in der IT-Branche am Beispiel von Thin-Clients und PCs, Projektbericht, Fraunhofer UMSICHT, Oberhausen

Pacholak, Piotr (2010): Ressourceneffizienzpotenziale durch neuartige Formen von „Nutzen statt Besitzen“ bei Montageanlagen. Diplomarbeit, Technische Universität Berlin, Institut für Werkzeugmaschinen und Fabrikbetrieb, Fachgebiet Montagetechnik und Fabrikbetrieb, Berlin

Reichardt, Björn (2010): Ressourceneffizienzpotenziale von Elektrofahrzeugen. Interner Bericht, Institut für Leichtbau und Kunststofftechnik, TU Dresden

Rohn, Holger / Pastewski, Nico / Lettemeier, Michael (2009): Identification of technologies, products and strategies with high resource efficiency potential. Resource efficiency Paper 1.3. Wuppertal Institute. Wuppertal.

Rohn, Holger / Pastewski, Nico / Lettemeier, Michael (2010a): Resource efficiency of selected technologies, products and strategies. Executive Summary. Resource efficiency Paper 1.7. Wuppertal Institute. Wuppertal.

Rohn, Holger / Pastewski, Nico / Lettemeier, Michael (2010b): Technologien, Produkte und Strategien Ergebniszusammenfassungen der Potenzialanalysen". Ressourceneffizienz Paper 1.5. Wuppertal Institut. Wuppertal.

Rothenberg, Sebastian (2010): Ressourceneffizienz durch Leichtbau. Interner Bericht. TU Dresden

Sadeghi, Masi / Kuhrke, Benjamin (2010): Ressourceneffizienzpotenziale durch Umsetzung des Leuchtbaus unter Nutzung neuartiger Werkstoffe. In: Rohn, Holger / Pastewski, Nico / Lettenmeier, Michael (2010): Technologien, Produkte und Strategien - Ergebnisse der Potenzialanalysen. Ressourceneffizienzpaper 1.5., Wuppertal Institut. Wuppertal.

Samus, Tobias (2010): Ressourceneffiziente Energieerzeugung: Potenziale von Desertec-Strom. Masterarbeit, Universität Kassel

Schimanski, Lisa Marie (2010): Ressourceneffizienzpotenziale der Intelligenten Landtechnik am Beispiel des Einsatzes von Stickstoffsensoren bei der Düngung. Bachelorarbeit, Technische Universität München / Lehrstuhl für Agrarsystemtechnik Institut für Werkzeugmaschinen und Fabrikbetrieb sowie Technische Universität Berlin / Fachgebiet Montagetechnik und Fabrikbetrieb, München

Schmidt-Bleek, Friedrich / Bringezu, Stefan / Hinterberger, Fritz / Liedtke, Christa / Spangenberg, Joachim / Stiller, Hartmut / Welfens, M. Jolanta (1998): MAIA Einführung in die Material-Intensitäts-Analyse nach dem MIPS Konzept, 1st ed.; Birkhäuser: Berlin, Germany

Schniering, Christoph. (2010): Ressourceneffizienzpotenziale von Dämmstoffen in WärmedämmVerbundsystemen, RWTH Aachen

Seitz, Manuela (2010): Ermittlung von Ressourceneffizienzpotenzialen der Energiespeicherung ressourceneffiziente Wärmespeicher, Institut für Produktionstechnik und Logistik, Fachgebiet Umweltgerechte Produkte und Prozesse, Kassel

Simon, Verena / Bernotat, Anke / Lettenmeier, Michael (2010): Ressourceneffizienzkriterien im Design am Beispiel Mobiltelefon. In: Rohn, Holger / Pastewski, Nico / Lettenmeier, Michael (2010): Technologien, Produkte und Strategien - Ergebnisse der Potenzialanalysen. Ressourceneffizienzpaper 1.5., Wuppertal Institut. Wuppertal

Stöwer, Lene (2010): Potenziale zur Ressourceneffizienzsteigerung in der Lebensmittelproduktion am Beispiel Gemüse. Projektbericht FH Münster, FB Oecotrophologie, Münster 
Udes, Jan (2010): Ressourceneffizienzpotenziale beim Recycling von Elektro- und Elektronikaltgeräten durch Rückgewinnung aus dem Hausmüll mit Hilfe einer RFID-Kennzeichnung der Primärprodukte. Studentische Arbeit, Institut für Werkzeugmaschinen und Fabrikbetrieb, Fachgebiet Montagetechnik und Fabrikbetrieb, Juni 2010

Werner, Katrin / Geisendorf, Sylvie / Lang, Bastian (2010): Green IT - Ressourceneffizienzsteigerung bei IKT Displaytechnologien im Vergleich. In: Rohn, Holger / Pastewski, Nico / Lettenmeier, Michael (2010): Technologien, Produkte und Strategien - Ergebnisse der Potenzialanalysen. Ressourceneffizienzpaper 1.5., Wuppertal Institut. Wuppertal.

Wiesen, Klaus (2010): Ermittlung von Ressourceneffizienzpotenzialen der regenerativen Stromerzeugung durch Windenergie und Biomasse in Deutschland - Erweiterte Fassung. Projektbericht, Institut für Produktionstechnik und Logistik, Fachgebiet Umweltgerechte Produkte und Prozesse

Wuppertal Institute. Material Intensity Factors-Overview on Materials, Fuels, Transport Services and Food. Available online: http://wupperinst.org/en/info/details/wi/a/s/ad/365/ (accessed on 22 April 2013). 